\title{
Perilaku Hedonisme Pada Wanita Sosialita
}

\section{Hedonism on Woman Socialites}

\author{
Alex Wulan Fahri Lumban Tobing ${ }^{1}$ \\ ${ }^{1}$ Fakultas Psikologi, Universitas Airlangga Surabaya \\ alexfahri@gmail.com
}

\begin{abstract}
Abstrak
Penelitan ini bertujuan untuk memberikan gambaran mengenai perilaku hedonisme pada wanita sosialita. Penelitian ini menggunakan tipe penelitian studi kasus instrumental dengan melibatkan 5 (lima) orang partisipan penelitian yang terlibat dalam beberapa grup sosialita di Surabaya. Partisipan kemudian diwawancarai dengan menggunakan wawancara semi terstruktur untuk mengetahui gambaran mengenai perilaku hedonis pada wanita sosialita. Hasil penelitian menunjukkan bahwa partisipan cenderung menganggap bahwa perilaku hedonis di kalangan wanita sosialita merupakan sebuah bentuk interaksi sosial di jaman modern yang juga terjadi di kelompok sosial lainnya. Hasil penelitian juga menunjukkan faktor yang membentuk perilaku hedonisme antara lain adalah konsep diri terkait dengan bagaimana partisipan menilai dirinya berdasarkan produk yang dipakai sebagai pembeda dirinya dengan masyarakat di kelas sosial lainnya. Faktor lain yang mendukung perilaku hedonisme adalah struktur norma yang telah terbentuk dalam komunitas sosialita yang diikuti sehingga hal tersebut menjadi standar yang harus diikuti oleh anggota komunitas sosialita.
\end{abstract}

Kata kunci: hedonisme, sosialita

\begin{abstract}
The focus of this research is to give descriptions on hedonic behavior on socialite women. The research is an Instrumental Study Case and involved 5 (five) female participants whom been active in several socialite groups in Surabaya. The participant was then interviewed with the semi-structured interview method to gain information about the hedonic behavior on socialite women. The research results that most of the participants view the hedonic behavior in a socialite group as a form of a modern social interaction that also happened in other social communities. Factors that shape the hedonic behavior are the self-concept regarding on how socialite value themselves based on what products or brands that distinguish them from the other people. The other factor is the standard that already established in the community. Those values are considered as an obligation which should be followed by all the community member of the socialite groups.
\end{abstract}

Keywords: hedonism, socialite

\section{Pendahuluan}

Arus globalisasi dan modernitas membawa dampak yang signifikan terhadap masyarakat perkotaan. Semakin derasnya akses informasi dan terbukanya kesempatan untuk terhubung dengan dunia luar mengubah pola pandang seseorang terhadap lingkungan sekitarnya. Modernisasi seringkali dikaitkan dengan westernisasi karena prakteknya didasarkan pada negara Barat. Hal ini seperti dikatakan oleh Soekanto (2006: 304) bahwa modernisasi mencakup segala aspek sesuatu yang tradisional ke arah pola ekonomis dan politik yang menjadi ciri-ciri negara-negara Barat stabil. Dampak ekonomis dari modernisasi adalah invasi produk asing dan pola hidup instan yang masuk ke dalam negeri. Produk-produk asing tersebut dikemas semenarik mungkin untuk meningkatkan minat beli konsumen. Adanya keinginan untuk membeli suatu produk secara berlebihan merupakan awal munculnya perilaku konsumtif. Individu akan secara terus menerus membeli barang hanya berdasarkan 
apa yang mereka inginkan, bukan berdasarkan apa yang dibutuhkan. (Fitriyani, Widodo, Fauziah, 2013).

Ironisnya perilaku seperti itu tidak hanya dilakukan oleh kaula muda, tapi juga mewabah pada kalangan dewasa atau orang tua (Safuwan: 2007). Perilaku konsumtif ini kemudian dikaitkan juga dengan pola hidup hedonisme. Jeremy Bentham dalam Poespoprodjo (1999) mengatakan bahwa kesenangan dan kesedihan itu adalah satu satu motif yang memerintah manusia. Kelompok hedonis biasanya melakukan kegiatan yang berfokus kepada diri sendiri dan bersifat mengeksploitasi kekayaan dan menampilkan perilaku hidup yang berlebihan. Aktivitas yang dilakukan biasanya berpusat seputar belanja di pusat perbelanjaan dan melakukan kegiatan dengan tujuan bersenang-senang di tempattempat hiburan umum. Banyak aktivitas dari kelompok hedonis ini kemudian berkembang di berbagai komunitas di perkotaan.

Kegiatan berkumpul dan bersenang-senang ini kemudian diidentifikasi oleh masyarakat sebagai sebuah pola yang melekat pada kelompok ini. Menurut Sutrisno (2012), wanita adalah kaum yang besar kemungkinan untuk dikaitkan dengan perilaku hedonis. Pada kelompok wanita, hedonisme kerap diasosiasikan dengan kelompok yang disebut "sosialita". Menurut Putri (2018) fenomena sosialita telah menjadi wacana di berbagai kalangan masyarakat, tidak hanya pada kalangan menegah ke atas, namun juga pada kalangan masyarakat menengah ke bawah. Sosialita kerap dihubungkan dengan perilaku hidup mewah dan selalu berupaya untuk menempatkan diri pada strata sosial yang paling tinggi di dalam masyarakat. Keberadaan sosialita dianggap masyarakat lebih banyak memberikan dampak negatif karena kegiatan mereka dinilai tidak memperhatikan kondisi masyarakat sekitar. Catharina Girsang (2015) bahkan merujuk hedonisme menjadi faktor utama perempuan bisa tersangkut kasus korupsi. Di samping itu, sosialita juga dianggap memiliki hobi yang tidak produktif dan terkesan hanya untuk menegaskan status eksistensi dan eksklusivitas di tengah masyarakat. Sosialita tak ubahnya seperti sindrom yang muncul ditengah-tengah masyarakat metropolitan, yaitu masyarakat yang dicirikan dengan sisi ekonominya yang tinggi, industrialisasinya yang maju, serta modernitasnya yang canggih. Eksistensi mereka seakan merupakan dampak dari proses modernisasi yang tengah melanda seluruh negara di dunia.

Pada perkembangannya, kelompok sosialita kemudian menjadi salah satu ikon dari budaya masyarakat perkotaan. Kota-kota besar di Indonesia menjadi wadah bagi aktivitas eksklusif sosialita salah satunya terbukti dengan komunitas artis dan istri pejabat yang mengadakan kegiatan mewah bernilai hingga puluhan bahkan ratusan juta rupiah yang menjamur di kota-kota besar di Indonesia. Wanita penggiat komunitas eksklusif semacam ini selain sering melakukan kegiatan konsumtif juga kerap mengabadikan kegiatan mereka melalui media sosial, hal ini juga semakin membuktikan kekuatan media sosial sebagai salah satu wadah untuk mendongkrak popularitas dan eksistensi mereka. Pemahaman yang awam mengenai makna sosialita muncul pada sebagian besar masyarakat. Ketika mendengar kata "sosialita", hal yang sering muncul dalam pikiran masyarakat tidak jauh dari barang bermerk dan mewah, tamasya keluar negeri, dan arisan dengan nominal mencapai ratusan juta rupiah. Gaya hidup yang cenderung high-class dengan barang mewah dan jauh dari kata "murahan" (Putri: 2018). Sebagian besar dari golongan masyarakat menganggap bahwa untuk menjadi sosialita berarti harus memiliki barang bagus dan bermerk, beraktivitas di kafé terkenal, jalan-jalan ke luar negeri dan kegiatan lain yang intinya adalah menghamburkan kekayaan untuk diri sendiri. Pemahaman yang demikian kemudian menjadi sebuah nilai hedonis yang sudah melekat dan menjadi identitas sosial bagi kaum sosialita. Perilaku hidup hedonisme pada kelompok sosialita ini pada akhirnya menjadi tren di masyarakat. Para wanita kemudian mulai mencontoh pola hidup para sosialita dengan tujuan mendapatkan identitas sosial yang serupa. Mereka yang pada akhirnya bergabung atau membentuk kelompok sosialita baru tersebut tidak jarang rela melakukan segala cara agar mendapat pengakuan atau sekedar mempertahankan status dan label sosialita. Hasil penelitian yang dilakukan oleh Lukitasari \& Muis (2016) menunjukkan bahwa kecenderungan gaya hidup hedonis sebagian besar ditunjukkan dengan adanya sikap berbelanja dan mengoleksi barang-barang bermerek, mengisi waktu luang dengan mengunjungi tempat nongkrong di tempat hiburan yang sering dikunjungi oleh para selebrita. Hal lain yang dilakukan adalah membeli berbagai barang yang dikenakan oleh sosialita pujaannya. Hasil penelitian lain yang dilakukan oleh Putri (2018) menunjukkan bahwa dalam melakukan kegiatan konsumsi, sosialita ingin membangun identitas melalui produk-produk bermerek yang mereka kenakan.

Permasalahan muncul ketika banyak dari anggota komunitas ini yang pada dasarnya tidak mampu untuk menjalani profil sebagai wanita sosialita. Wanita dengan kemampuan finansial yang lebih akan lebih mudah menjalani perilaku hidup hedonis yang berjalan beriringan dengan status sosialita 
mereka, namun lain halnya dengan wanita yang memiliki kemampuan finansial yang kurang. Wanita di tingkat finansial seperti ini sejatinya hanya mampu memenuhi keperluan mereka sehari-hari. Bergabung di dalam kelompok sosialita tentunya akan membuat mereka mengalami kesulitan untuk menyesuaikan diri dengan norma yang ada. Di satu sisi, kelompok sosialita seakan menjadi wadah bagi siapa saja yang memiliki kebutuhan untuk diakui. Kebutuhan untuk diakui ini kemudian memunculkan suatu dorongan untuk mencapai kondisi dimana seseorang dapat merasa bahwa ia diakui dan dibutuhkan keberadaannya di dalam kelompok. Hal ini menjelaskan mengapa anggota sosialita, terlepas dari kemampuan finansial mereka, seakan memiliki kewajiban semu untuk terus berada dalam komunitas sosialita tersebut, bahkan dengan berperilaku diluar kebutuhan dasar mereka.

Hedonisme berasal dari bahasa Yunani, hedonismos dari akar kata hedone yang berarti kesenangan (O'shaughnessy, Jhon, \& Nicholas J.O, 2002: 13). Menurut Oxford (2003), hedonisme adalah kepercayaan bahwa kesenangan dan pemuasan diri adalah tujuan dari kehidupan yang sesungguhnya. Menurut Bentham (dalam Allport \& Gordon, 1954: 88), konsep hedonisme menggambarkan segala cara yang dapat menimbulkan kesenangan dan baik untuk dilakukan. Hedonisme dapat didefinisikan sebagai nilai yang dimiliki individu dan mempengaruhi perilakunya untuk mencapai kesenangan tersebut. Bentham juga berpendapat bahwa kesenangan seharusnya adalah sesuatu yang dapat diterima oleh masyarakat sebagai sesuatu yang baik. Dengan kata lain, kesenangan adalah baik jika dapat diterima dan dinikmati oleh sebagian besar masyarakat, hal ini dapat dilihat dari slogan para utilitarian, "the greatest happiness for the greatest number".

Gaya hidup hedonis menurut Solomon (2007: 131) merupakan perilaku atau kebiasaan seorang individu untuk menghabiskan waktunya hanya demi bersenang-senang bersama teman sepermainan dan ingin menjadi pusat perhatian di lingkungannya. Aktivitas apapun yang dilakukan demi mencapai kenikmatan: bagaimanapun caranya, apapun sarannya, dan apapun akibatnya (A.A Kunto, 1999: 32). Sementara itu Chaplin dalam Theo \& Heru (2009) beranggapan bahwa dari perspektif teori psikologi, dinyatakan bahwa individu itu memilih berperilaku hedonis sedemikian rupa untuk mencari kesenangan dan menghindari kesakitan.

Sebagai sebuah konsep, hedonisme memiliki beberapa dimensi. Kotler (2005) menyebutkan bahwa aspek gaya hidup hedonisme terdiri dari tiga hal, yaitu aktivitas, minat, dan kepentingan. Aspek aktivitas berarti setiap perilaku yang muncul dari individu untuk mengejar perilaku hedonisme. Aspek minat meliputi pusat perhatian individu yang dapat disimpulkan sebagai obyek dari hedonisme, misalnya barang-barang mewah atau jumlah pengikut di media sosial. Aspek kepentingan meliputi sejauh mana suatu sebab dapat membuat seseorang pada akhirnya mencari kesenangan dalam hidupnya. Aspek ini juga memiliki makna sejauh mana individu melihat perilaku hedonisme ini penting bagi hidupnya. Sementara itu menurut Susanto (2001: 63) aspek-aspek gaya hidup hedonis yaitu bagaimana konsumen menggunakan waktunya (aktivitas), lingkungan mana yang mereka anggap penting (minat) dan bagaimana mereka melihat diri dan dunia sekelilingnya (opini). Dari ketiga aspek ini, sebuah kelompok dapat diindikasikan memiliki perilaku hedonisme.

Menurut Kotler (1998), faktor yang mempengaruhi gaya hidup hedonis antara lain adalah faktor internal dan eksternal. Faktor internal meliputi sikap, pengalaman, pengamatan, kepribadian, dan konsep diri. Sikap diartikan sebagai cara pandang dan kecenderungan untuk bertindak. Pengalaman diperoleh dari hasil interaksi manusia dengan lingkungannya. Pengamatan seseorang dipengaruhi oleh hasil persepsi panca indera dan dipahami melalui proses identifikasi. Kepribadian adalah susunan karakteristik individu dan cara berperilaku yang menentukan perbedaan perilaku setiap individu. Sedangkan konsep diri berperan dalam meregulasi diri untuk dapat merespon setiap stimulus dari luar.

Faktor eksternal yang mempengaruhi gaya hidup hedonis adalah kelompok referensi, keluarga, kelas sosial, dan kebudayaan. Kelompok referensi merupakan kelompok yang memberikan pengaruh langsung atau tidak langsung terhadap sikap dan perilaku seseorang. Interaksi individu dengan kelompok referensi dapat mempengaruhi perilaku hedonis individu tersebut. Keluarga dapat memberikan pengaruh terhadap pengambilan keputusan untuk melakukan suatu tindakan hedonisme. Pola asuh orangtua diketahui berdampak dalam membentuk kebiasaan anak yang akan mempengaruhi pola hidupnya. Kelas sosial mengarah pada perbedaan status ekonomi dan sosial yang akan mempengaruhi perilaku dan gaya hidup. Sementara kebudayaan meliputi pengetahuan, kepercayaan, kesenian, moral, hukum, adat istiadat, dan kebiasaan yang diperoleh individu sebagai bagian dari masyarakat.

Sosialita awalnya adalah sebuah akronim yang diserap dari bahasa Inggris, berasal dari kata "social" dan "elite". Kata "social" sebagai kata sifat memiliki arti suka memperhatikan kepentingan umum (suka menolong, berderma, dan sebagainya). Arti lain dari kata tersebut adalah setiap kegiatan 
yang berkenaan dengan masyarakat/sosial. Sedangkan makna kata "elite" sebagai kata benda memiliki arti "orang-orang terbaik atau pilihan di suatu kelompok". Yang dimaksud dengan kelompok ini adalah sekumpulan orang-orang terpandang atau berderajat tinggi (kaum bangsawan, cendekiawan, dan sebagainya) yang hidup sebagai bagian dari kelas atas di sebuah kota/negara. Dengan demikian dapat disampaikan bahwa makna asli dari sosialita adalah kumpulan orang yang memiliki derajat tinggi/terpandang dan yang memiliki jiwa sosial terhadap orang-orang yang kurang mampu/berada di bawah kelas sosial mereka. Dalam perkembangannya, pemaknaan sosialita ini hanya bertahan sesaat, digantikan oleh pemaknaan yang lebih memiliki konotasi negatif, salah satunya pengaitan sosialita dengan hedonisme.

Oleh karena itu, rumusan masalah penelitian ini adalah bagaimana gambaran perilaku beserta faktor yang mempengaruhi berkembangnya perilaku hedonisme di kalangan sosialita. Tujuannya adalah untuk mengetahui perilaku yang terbentuk wanita sosialita tentang perilaku hedonisme berikut faktor pembentuk perilaku tersebut.

\section{Metode Penelitian}

Penelitian ini mengambil sumber utama dari 5 (lima) orang partisipan yang menjadi anggota pada berbagai komunitas sosialita (DE, DM, KW, RI, dan YS). Jenis penelitian yang dilakukan adalah penelitian kualitatif dengan pendekatan studi kasus instrumental dengan tujuan memperoleh data yang lebih mendalam. Data penelitian diperoleh melalui metode wawancara serta studi kepustakaan. Wawancara merupakan metode pengumpulan data melalui interaksi tatap muka dengan partisipan dengan menyampaikan sejumlah pertanyaan terkait dengan topik hedonisme dan sosialita. Studi kepustakaan merupakah metode yang digunakan untuk memperoleh data berupa teori yang berkaitan dan mendukung penelitian. Data yang dikumpul dianalisis dengan pendekatan deskriptif interpretatif yaitu analisa berupa penjelasan mendalam dengan penafsiran atau pemaknaan terhadap gejala yang diteliti. Tujuan dari teknik analisis tersebut adalah untuk memberikan gambaran jelas mengenai perilaku hedonis pada wanita sosialita dan apa saja faktor-faktor yang berpengaruh terhadap terbentuknya perilaku tersebut.

\section{Hasil Penelitian}

Partisipan KW, DE, DM, YA, dan RI memiliki beberapa asumsi yang berbeda tentang mengapa kaum sosialita didominasi oleh wanita. KW dan DM misalnya menganggap bahwa kaum wanita lebih mendominasi perkumpulan sosialita karena memang hakikatnya para wanita lebih perlu untuk berbicara dan bersenda gurau. Sementara DE, YA, dan RI berpendapat bahwa para wanita cenderung memiliki lebih banyak bakat yang berhubungan dengan komunitas dibanding kaum pria. Menurut mereka, pria cenderung lebih solitaire dan menyukai kesendirian dalam beraktivitas. Kelima partisipan juga setuju bahwa hakikat wanita adalah untuk berkumpul dan berorganisasi dengan berbagai macam persamaan (alasan religiusitas, profesi, hobi, dsb.). Mereka juga setuju bahwa wanita akan lebih banyak memerlukan komunitas daripada pria yang cenderung kompetitif, maka wajar apabila komunitas sosialita didominasi oleh wanita.

Untuk jenis pengeluaran, kelima partisipan memiliki beberapa jenis kegiatan yang beragam. Menurut intensitasnya, KW dan DM lebih suka untuk berbelanja dan jalan-jalan, sementara YS, RI dan DE memilih aktivitas nongkrong sebagai bentuk pencarian kesenangannya. Sedangkan untuk besar biaya yang diperlukan, kelima partisipan beranggapan bahwa hal tersebut sangat relatif. Ketika memang diperlukan, maka besaran biaya dapat menjadi sangat besar.

Jenis produk yang mereka konsumsi atau pakai pun beragam, namun mereka sepakat bahwa kebanyakan dari mereka mengonsumsi produk-produk dari Barat, seperti merk dari Eropa dan Amerika.

Terkait dengan eksistensi mereka, partisipan setuju bahwa kaum sosialita akan selalu memerlukan media dimana mereka dapat berekspresi dan menunjukkan keberadaan mereka. Partisipan RI dan KW mengaku bahwa mereka senang memuat segala aktivitas mereka di media sosial yang mereka miliki, sedangkan DM, YS, dan DE memilih untuk lebih eksis dalam hal memberikan informasi terakit dengan barang yang mereka beli/konsumsi. Abadi (tanpa tahun) menyebutkan bahwa nilai sosial pada diri sosialita didapatkan dari interaksi yang dilakukan, baik itu dengan orang lain, pemberitaan dari media dan juga berasal dari pengalaman saat berhubungan dengan dunia sosialita. 


\section{Pembahasan}

Sehubungan dengan aktivitas hedonis yang dilakukan, kegiatan yang dilakukan oleh kaum sosialita akan selalu berputar pada aktivitas yang membawa kesenangan. Pada intinya, setiap kegiatan yang mereka lakukan pada dasarnya harus memberi manfaat kebahagiaan dan bukan kesusahan. Hal ini sesuai dengan Veenhoven (2003) yang menganggap bahwa seseorang memiliki gaya hidup hedonis akan selalu berorientasi kepada kebahagiaan, kesenangan secara sepihak, dan memanfaatkan hal tersebut untuk mencapai tujuan yang diharapkan.

Oleh karena tujuan yang hendak dicapai adalah kesenangan semata, gaya hidup hedonis akan selalu membutuhkan biaya yang besar. Kesenangan hidup akan dilihat dari hasil kesuksesan materi, sehingga dapat di katakan bahwa uang, harta, kekayaan, dan kemewahan hidup adalah norma mereka. Norma yang dimaksud adalah sebagai standar dalam kaum hedonis menakar seberapa besar kebahagiaan yang mereka ingin dapatkan (Rianton: 2013).

Chaney (2000) lalu berpendapat bahwa perilaku hedonisme akan selalu berorientasi kepada gaya hidup masyarakat dari luar negeri. Hal ini terjadi karena perilaku hedonisme memang muncul sebagai akibat dari akulturasi dengan gaya hidup budaya barat. Pembelian barang bermerk dan mewah yang berasal dari luar negeri dianggap dapat meningkatkan status sosial seseorang. Gaya hidup hedonis adalah suatu pola hidup yang aktivitasnya untuk mencari kesenangan hidup, lebih banyak waktu dalam menikmati waktu diluar rumah dan mengkonsumsi barang-barang yang memiliki merk terkenal.

Sejalan dengan hal ini Baudrillard (1994) memiliki beberapa konsep yang dapat dikaitkan dengan kondisi konsumerisme dalam sosialita, antara lain adalah konsumsi simbol, simulacrum, hiperrealitas, distingsi dan sampah visual. Menurut Baudrillard, konsumsi simbol menjabarkan terjadinya perubahan dari "kebutuhan hidup" menjadi "gaya hidup". Invasi produk Barat ke negara-negara berkembang menjadikan manusia cenderung mengonsumsi merk daripada fungsi dari sebuah produk. Simulacrum atau simulakra bekerja dengan menciptakan imajinasi dan hal-hal yang sifatnya fantasi dan salah satu karakter sosialita yang sering dijumpai adalah tipikal pemikiran yang cenderung menyukai hal-hal bernuansa kemewahan yang terkadang di luar akal sehat. Hiperrealitas menunjuk pada segala sesuatu yang bersifat melampaui kenyataan, misalnya, iklan sabun mandi yang mampu membuat wanita menjadi pusat perhatian seluruh laki-laki yang melihatnya atau iklan multivitamin yang dapat membuat anak cerdas seketika. Hal tersebut akhirnya dimaknai oleh masyarakat sebagai kebenaran dan harus dicoba atau dimiliki. Inovasi pemasaran ini menarik perhatian para sosialita untuk mengikuti tren dengan memiliki barang yang sedang menjadi tren tersebut. Tujuannya agar mereka tetap dapat diakui eksistensinya. Distingsi adalah suatu pembedaan yang dibuat atau diakibatkan oleh pilihan selera dari para sosialita. Hal ini terlihat dari pilihan mereka untuk membeli barang dengan merk ternama dengan tujuan untuk membedakan diri dari kalangan kebanyakan. Sedangkan sampah visual terjadi akibat adanya sebuah standar dari produsen yang ditetapkan dan diiklankan lalu mendistorsi alam pikiran mereka yang melihatnya. Hal ini dapat terjadi misalnya ketika sebuah iklan tentang pemutih wajah dibawakan oleh seorang model yang cantik, hal tersebut mampu mendistorsi pemahaman masyarakat akan kenyataan bahwa sebenarnya model tersebut sudah cantik tanpa produk tersebut. Akhirnya, banyak orang akan membeli produk tersebut tanpa memperhatikan pertimbangan rasio dalam membeli produk tersebut. Kelima faktor tersebut merupakan elemen penting yang dapat dijadikan acuan mengapa kaum sosialita seakan memiliki perilaku konsumtif yang tidak akan pernah habis, bahkan terlepas dari kemampuan finansial yang mereka miliki.

Faktor pendorong terbentuknya perilaku hedonis pada sosialita ini juga terletak pada kebutuhan akan berafiliasi. Pratiwi (2015) berpendapat bahwa kaum sosialita sangat senang berada di tengah keramaian. Bagi kelompok sosialita, berada bersama dengan teman sejawat mampu membuat mereka melupakan kepenatan rutinitas mereka sebagai ibu rumah tangga. McClelland (1961) menyebutkan bahwa motif berafiliasi yang tinggi cenderung dimiliki oleh kaum wanita sosialita. Gaya hidup glamour wanita sosialita berangkat dari kebutuhan untuk mendapatkan pengakuan dari masyarakat dan kelompoknya. Secara bersama-sama, kelompok sosialita memiliki kepercayaan diri yang tinggi untuk mengaktualisasikan setiap keinginan dan kelebihan dalam dirinya. Dampak dari adanya kebutuhan berafiliasi ini juga nampak dari adanya anggota yang memiliki kecenderungan merasa eksklusif karena sudah tergabung di dalam komunitas sosialita. Fenomena social climber/panjat sosial juga banyak terjadi karena beberapa wanita anggota komunitas sosialita memiliki motivasi untuk ikut tampil walaupun baru saja bergabung atau tidak memiliki kekayaan yang setara dengan anggota lainnya. 


\section{Kesimpulan}

Natur wanita yang selalu ingin berkelompok membuatnya erat dikaitkan dengan komunitas sosialita. Komunitas sosialita dapat dikatakan merupakan produk dari modernisasi dan merupakan bagian dari masyarakat modern di perkotaan. Dampak modernisasi memberikan pengaruh bagi gaya hidup yang mengadopsi masyarakat Barat. Perilaku hedonisme pada sosialita merupakan bentuk dari keinginan untuk memperoleh kesenangan. Faktor internal dari perilaku sosialita adalah bagaimana mereka memandang diri mereka berbeda dari komunitas lainnya, sehingga pada kelompok sosialita, terdapat kecenderungan untuk mengidentifikasikan anggota grup berbeda dari grup lainnya. Proses pemaknaan yang terjadi pada komunitas sosialita dapat diidentifikasi dari kegemarannya untuk selalu berusaha tampil berbeda dari masyarakat pada umumnya. Budaya yang telah terbentuk pada komunitas juga akhirnya menjadi standar bagi setiap perilaku anggota komunitas sosialita, sehingga hal tersebut lambat laun semakin mengokohkan sistem norma di dalam komunitas tersebut. Faktor lain yang mempengaruhi terbentuknya perilaku hedonis ini antara lain adalah kebutuhan akan pengakuan dari masyarakat yang menyebabkan seorang anggota dari komunitas sosialita akan menakar nilai dirinya sendiri berdasarkan oleh apa yang dipandang bernilai lebih di masyarakat. Kebutuhan akan berafiliasi tersebut juga pada akhirnya menyebabkan terjadinya fenomena social climber yang terkadang merugikan komunitas sosialita yang diikutinya.

\section{Daftar Pustaka}

Abadi, C. (tanpa tahun). Konstruksi Makna Sosialita Bagi Kalangan Sosialita di Kota Bandung. disadur dari https://elib.unikom.ac.id/files/disk1/763/jbptunikompp-gdl-rezayulian-38105-2-unikom_4-1.pdf.

Allport, W. \& Gordon C.S. (1954). Social Psychology (3rd Edition). USA. Addition Wesley.

Baudrillard, J. (1994). Simulacra and Simulatio. translated by Sheila Glaser. University of Michigan Press.

Chaney \& Bitta. (2000). Perilaku Konsumen. Jakarta. Binarupa Aksara.

Chaplin, J. (2002). Kamus Lengkap Psikologi. (Alih Bahasa: Kartini Kartono), Jakarta: PT. Grafindo Persada.

Fitriyani, N., Widodo, P. B., \& Fauziah, N. (2013). Hubungan antara konformitas dengan perilaku konsumtif pada mahasiswa di Genuk Indah Semarang. Jurnal Psikologi Undip. 12(1), 55-68.

Girsang, C. (2015). Hedonisme Jadi Penyebab Perempuan Tersangkut Korupsi. disadur dari https://news.detik.com/berita/2899403/chatarina-girsang-hedonisme-jadi-penyebab-perempuantersangkut-korupsi.

Joy, R., Mulya, N. (2013). The Untold Stories of Arisan Ladies and Socialites. PT Gramedia Pustaka Utama.

Kottler, P., Keller, Kevin L. (2005). Marketing Management. Prentice Hall.

Kottler, P. (1988). Manajemen Pemasaran :Analisis, Perencanaan, Implementasi. Jakarta. Erlangga.

Kottler, P. \& Armstrong, G. (2006). Dasar-Dasar Pemasaran Jilid 1. Jakarta. PT. Indeks.

Kunto, A.A. (1999). Kecil Bahagia, Muda Foya-foya, Tua Kaya Raya, Mati Maunya Masuk Surga. Yogyakarta. Kanisius.

Lukitasari, V., \& Muis, T. (2016). Studi Tentang Gaya Hidup Hedonis pada Mahasiswa Fakultas Bahasa dan Seni Universitas Negeri Surabaya Angkatan Tahun 2012-2013, Jurnal BK Unesa. Vol. 6 No. 2. 
Maslow, A. (1943). A Theory of Human Motivation. Psychological Review.

McClelland, D. C. (1961). The Achieving Society. Princeton, New Jersey. D. Van Nostrand Company, Inc.

Murray, J. (2003). Concise Oxford English Dictionary. Oxford Press.

Poespoprodjo, W. (1999). Filsafat Moral. CV. Pustaka Grafika.

O'Shaughnessy, N. J. (2002). Marketing, the Consume Society and Hedonism. European Journal of Marketing. Volume 36, Iss: 5/6, 524-547.

Pratiwi, Alitha. (2015). Analisis Gaya Hidup Wanita Sosialita Strata Menengah di Kota Manado dari Perspektif Trikotomi Motif Sosial McClelland. Jurnal Fakultas Ilmu Pendidikan (JFIP). Vol 3, No 1.

Putri, S. M. S. S. (2018). Makna Gaya Hidup "Brand Minded" Pada Konsumen Sosialita. IDEA (Jurnal Humaniora). Vol 1, No. 1.

Rianton. (2013). Hubungan antara konformitas kelompok teman sebaya dengan gaya hidup hedonis pada mahasiswa kabupaten Dhamasraya di Yogyakarta. Jurnal Publikasi Fakultas Psikologi Universitas Ahmad Dahlan. Yogyakarta.

Safuwan. (2007). Gaya Hidup, Konsumerisme dan Modernitas. Jurnal SUWA Universitas Malikussaleh. Vol. V, No. 1.

Soerjono Soekanto. (2006). Sosiologi Suatu Pengantar. Jakarta. Raja Grapindo Persada.

Solomon, M. R. (2007). Consumer behavior; buying, having, and being. United State Prentice - Hall International, Inc.

Susanto, A.B. (2001). Potret-potret Gaya Hidup Hedonis. Jakarta. Kompas.

Sutrisno, D.A. (2012). Wanita dan Hedonisme. disadur dari https://www.kompasiana.com/didadidot/5510ea9ba333110137ba8f09/wanita-dan-hedonisme

Riyanto, T. \& Susanto, H. (2009). Mau Bahagia? Yogyakarta. Kanisus.

Veenhoven, R. (2003). Hedonism and Happiness. In: Journal of Happiness Studies. vol. 4. pp. 437-457. 